\title{
DIE WERK VAN DIE HEILIGE GEES IN SKEPPING EN HERSKEPPING.
}

\author{
Ds. G. D. Kruger
}

Abraham Kuyper het van Calvyn en die ander Hervormers gesê dat hulle slegs die eerste lyne van die leer oor die Heilige Gees getrek het (Kuyper 1893, 71v). Die nood van die kerk is volgens hom daarin geleë rlat die werk van die Gees tot heiligmaking beperk is (Velema sd. 7).

Maar ook Kuyper is van 'n beperkte insig in die werk van die Gees beskuldig: "Zijn scheppingsleer verhinderde hem, ondanks zijn oprechte begeerte en hartstochtelijke bedoelingen, een voluit gereformeerd pneumatologie op te bouwen ... de Heilige Geest . . . had geen aandeel aan het ontstaan van het leven" (ibid 244).

Verder het ook Bavinck Calvyn en die ander Reformatore gekritiseer dat hulle 'n eensydige Pneumatologie opgebou het (Bavinck $1930,1: 563)$. En Moody sê dat die Westerse kerk die werk van die Gees tot verlossing beperk ... "the Eastern Ortodoxy, which employes Ps. 104 in daily whorship, has vigorously challenged this confinement and contended for both a creative and a redemptive work of the Spirit. At least on this point the West can learn from the East (Moody 1976, 28). Maar Nürnberger kritiseer die Ooste weer juis m.b.t. die pneumatiese kosmologie (Nürnberger 1975, 383).

H. Berkhof het beide Van Ruler en Moltmann onder die loep geneem: "As Van Ruler sees it, the Spirit in his work of 'christianisation' reaches primarly backward, restoring the order of creation by means of a theocratic order in Calvin's sense ... According to Moltmann, the Spirit prepares the way towards the future and creates an 'exodus-church' which tries to transcend the established order in the direction of the future" (H. Berkhof 1979 509). Berkhof self pleit vir 'n christologies-pneumatologiese benadering, na analogie van persoonlike heiliging..

As ek my dan waag aan hierdie onderwerp moet $u$ nie van my 'n nuwe of laaste woord verwag nie. Ook in ons eie tyd kla baie dat daar nog nie 'n goeie pneumatologie opgebou is nie. Dit lyk asof elke teoloog wat sy pen opneem om te skryf, probeer om hierdie gebrek aan te vul sonder dat hy daarin slaag. Ook hierdie voordrag kan nie aan die onderwerp reg laat geskied nie. Wie kan tog die werke van God heeltemal ken? Nie ek nie; ek is nóg profeet, nóg historikus.

Mc Lelland meen dat die gebrek aan 'n volledige pneumatologie uit die feit spruit dat Hy voor alles liefde bewerk. "You cannot doctrinaire about love ... (it) ... is far better to honour the Spirit by illustrating our doctrine of Christian life, especially of its joy (Mc. Lelland 205).

As $u$ dan saam met my in vreugde besin oor die werk van die Gees in skepping en herskepping, hoop ek dat ons hierdeur versterk sal word om God se Woord met woord en daad te verkondig totdat Hy wat die Gees as Eersteling gestuur het, alles nuut maak. 


\section{Dualisme of openbarings-historiese perspektief?}

Hattingh beweer met reg dat die leer oor die Heilige Gees teenoor elke dualistiese opvatting oor die verhouding van God en die Wêreld, van groot belang is (Hattingh 1965 5). Ook Blaser (1977 14) ken hierdie funksie aan die Pneumatologie toe. Verryn (1980 4) sê: "The most fundamental distinction between the 'enthusiast and 'the rest' . . . is not the claim to have the Holy Spirit, but relates their differing theologies of nature and grace".

Nou kan 'n mens by sekere "charismatici" 'n baie besliste dualisme raaksien: die Gees doen wonders in die persoonlike innerlike sfeer en by spesiale geleenthede, maar vir die gewone lewe van elke dag het Hy nie soveel te sê nie. Maar ook Kuyper is nie ten onregte nie beskuldig van 'n versluierde dualisme (Velema sd. 222). Verder merk Mc. Lelland 'n dualisme by die gereformeerde Pneumatologie op, nl. díe tussen kerk en wêreld.

As 'n mens egter met Ridderbos (1971 89) en Versteeg (1980) raaksien dat die Gees by uitstek die eskatologiese Gawe is wat ons nie die bo-aardse nie, maar die nuwe-aardse lewe gee; as jy m.a.w. nie dualisties nie, maar openbarings- histories oor die werk van die Gees dink, sien jy duidelik ook die kosmologiese kante raak. So het Walters (1949 332) aangetoon dat dit juis Calvyn se Pneumatologie was wat hom van 'n radikale dualisme bewaar het.

Die hedendaagse teologie beweeg natuurlik nie in die rigting van dualisme nie, maar eerder van monisme waar die werk van die Gees totaal binne-wêrelds verstaan word (Schaeffer 1973; Blaser 1977 14). Jonker pleit vir 'n dualiteit van aardse en ewige heil, van skepping en herskepping, 'n dualiteit en nie 'n dualisme soos wat 'n mens by Kuyper opmerk nie. By Kuyper bestaan die neiging "... om die algemene werk van die Gees as iets min of meer selfstandigs naas sy besondere werk te sien." (Jonker 1981 270; Velema sd. 222).

In die stryd teen vertikalisme én horisontalisme is die regte verstaan van die werk van die Gees van deurslaggewende belang.

\section{DIE GEES EN DIE OORSPRONKLIKE SKEPPING.}

" . . en die Gees van God het gesweef op die waters" (Gen. 1:2), so lui die Skrif die werk van die Gees m.b.t. die skepping in. Verskillende teoloë het hierdie teks natuurlik op verskillende maniere uitgelê. "Ruach Elohim" sou dan op 'n groot wind dui wat op stryd heel in die begin van die skepping dui. Ook is ten onregte beweer dat "merachfet" met "broei" vertaal moet word. Maar met Helberg (in klaslesings) kan ons sê dat die Gees voorbereidend en instandhoudend besig was.

Maar wat beteken dit presies? Moet ons met Vriezen (1966 231) en Kuyper (volgens Velema sd. 244) sê dat die Ruach nie geskape het nie, maar net aktief teenwoordig was? (Vgl. ook Nürnberger $1975372,383) \mathrm{H}$. Berkhof praat van aktiewe teenwoordigheid én dat "The Spirit generates life". M.i. is Bavinck reg wat meen dat die skepping deur die ganse Triniteit gedoen is en dat daar nie arbeidsverdeling nie maar samewerking was (Bavinck 1929 386) met die Va- 
der vooraan. Calvyn maak in sy kommentaar op Genesis 1 nie skerp onderskeidinge nie, maar haal eenvoudig Ps. 104 in dié verband aan (Calvyn 1847 74).

In elk geval het Kuyper se filosofiese onderskeidinge dat die Gees besig was" ... with impregnating inanimate matter, animating the rational (!!) soul and taking up his abode in the elect child" (1975 24), nie skriftuurlikeksegetiese gronde nie. Hy meen selfs dat die Gees se werk eers ná die skepping van die stoflike met die ewige lewenskieme daarin begin het (29). Velema wys die idealistiese onderbou van hierdie beskouing duidelik aan. Ten spyte daarvan dat Kuyper teen die Idealisme wou ingaan, het hy tog van 'n idealistiese raamwerk gebruik gemaak en daarby beklemtoon dat die stoflike deel van die skepping nie ewig is nie (Velema sd. 77). Die essensie van alles het nl. ewig in die raad van God bestaan en wat die Gees gedoen het is om die geskape stof en die essensies met mekaar te versoen. Alhoewel hy uitvoerig skryf oor die "algemene werk van die Gees", het hy Hom geen wesentlike plek gegee in sy skeppingsleer nie, sodat hy self beweer: "De werkingen des Heiligen Geestes liggen alle op het verborgen terrein des harten" (Kuyper 18922 : 73). Hiermee hang ook sy beskouing oor die veronderstelde wedergeboorte saam.

Ook Nürnberger ('n Luteraan wat die Gees ondergeskik aan die Woord makk, 1975 383) ontken dat die Gees by die skepping betrokke was: Hy is die Skepper van die nuwe skepping in Christus (vgl. ook Blaser 1977 14).

God Drieënig het geskape. As die Gees nie deel daaraan gehad het nie, kan die leer oor die Gees nie anders as dualisties wees nie: die Gees lei dan nie die natuurlike lewe na sy doel nie, maar voeg "geestelike" sake by die geskapene. Berkhof beskryf hierdie werk van die Gees m.i. korrek as hy sê: "The Spirit . . . originates, maintains and develops the life of the natural creation (1979 511).

\section{DIE GEES EN DIE INDIVIDUELE GELOWIGE.}

Ek wil nie hier op al die aspekte van die ordo salutus ingaan nie, maar volstaan met enkele opmerkings i.v.m. wedergeboorte, die "liggaam", en die "vlees".

Volgens Kuyper is die besondere werk wat die Gees in die individu begin, dié van wedergeboorte. Dit is volgens hom die onmiddellike inplanting van die geloofsvermoë (1975) (405) in die (ongeskape) wese van die sondige mens. Jy weet dat jy weer gebore is deur geestelike bevinding (ibid 106v). Waar die wedergeboorte in die syn van die mens plaasvind, word die bewussyn van die mens vernuut deur bekering (ibid 99). Só werk die Gees die wedergeboorte sonder die verkondiging van die Woord. Die implikasie vir die hele veld van die praktiese Teologie is verreikend. Daarvolgens word verbondskinders nie opgeroep tot 'n radikale breek met die sonde nie (wortel-bekering), en word die alles bepalende invloed van die wedergeboorte gering geskat omdat dit in die wese van die mens plaasvind sonder dat hy dit weet. Die vraag is in hoeverre die 
praktyk van ons bediening bewustelik of onbewustelik deur hierdie dialekties-gebaseerde beskouing van Kuyper veroppervlakkig is.

Die feit is dat die Heilige Gees in al sy werk, ook in die wedergeboorte, by die natuurlike aansluit. $\mathrm{Hy}$ wil in genade die natuurlike lewe in sy totaliteit herstel, van die mag van die sonde verbreek en heenlei na die doel wat God gestel het (Bavinck $19293: 575$ ). Soos Walters sê: "Life lived under the canopy of the Spirit is not the negation of the present life but it's enhancing" (Walters 194 9335). Wat Hy doen is om die gewone geskape lewe te wederbaar en dit só na sy doel te lei (vgl. König 1976 51, 2 Kor. $2: 14-3: 18$ ).

In dié verband is die begrip "soma" van deurslaggewende belang. "soma" het volgens Versteeg 'n reasionele karakter (Versteeg 1980 378). Die "soma" stel ons in staat om met die wêreld te kommunikeer. Wat die Gees doen is nie om die "soma" uit te skakel nie, maar dit in diens te neem en dit onder die heerskappy van Christus te plaas (1 Kor. 6:19). "De gave van de Geest betekent geen diskwalifikatie van het 'soma' . . . maar de levendmaking van het 'soma' (ibid 377, 379). Die Gees realiseer die nuwe lewe, die eskatón in die "soma" deur dit onder heerskappy van die Kurios te plaas. Daarom het die werk van die Gees in en deur die individu (vgl. Van Rensburg 198132 ) die rykste kosmologiese implikasies soos dit in Romeine 8 duidelik word.

In Romeine 8 stel Paulus "Pneuma" en "sarkos" teenoor mekaar. Hierdie teenstelling is nie dié van 'n hoër-laer-skema nie, maar dié van die Gees as Eersteling, "apargé" en die "sarkos" as aanduiding van die menslike sondigheid sedert die val van Adam (Ridderbos $1971234 \mathrm{v})$. Die Gees is reeds aan die mensdom in die sondige bedeling gegee, en gee ons in hierdie bedeling 'n voorsmaak van die nuwe lewe op die nuwe aarde wanneer ons heeltemal volmaak sal wees. Daarom werk die Gees in die totale mens vernuwing. Só moet ons ook lewe, "peripatein" in alles wat ons doen (Versteeg 1980 349). Ons moet die regte instelling "fronein" hê om in alles aktief onder heerskappy van ons Here te lewe.

Maar hierdie nuwe lewe beteken nie dat 'n gelowige die probleme van die aarde ignoreer nie. Nee, juis omdat ons 'n voorsmaak het van die nuwe lewe, sug en kerm van ons al die lyde in hierdie tyd van die vlees. Dit is ook hoe die Gees vernuwend werk in die hele skepping. Die hele skepping sien sugtend, verlangend uit na die herskepping van die hoof en daarmee sy eie herskepping en verheerliking. Maar dit is nie net die wedergebore mens en die onderworpe skepping wat sug nie, ook die Gees sug (vs. 26).

Dit is tiperend vir die hele lewe van die individuele gelowige. Al sugtend sien ons verlangend uit na die vervolmaking van alles. Daarom is berusting sonde. "'n Christen wat tevrede is in 'n situasie op hierdie ou wêreld verloën die belofte dat die Gees nog net die Eersteling is" (König 1976 23), wat in die "soma" van die mens en daarom in al sy relasies die lewe van die nuwe skepping bewerk. Die heiligende werk van die Gees raak daarom nie net die hart of die gesindheid van die nuwe mens nie, maar sy totale lewe. So staan die nuwe mens in vyandskap, nie teen sy geskape persoonlikheid nie, 
maar teen die sondigheid wat hom in al sy verhoudinge gekenmerk het.

\section{DIE GEES, NASIONALISME-IMPERIALISME EN TERRORISME.}

Dat die Gees ook in ongelowiges werk word deur die meeste teoloë erken. Maar sedert ongeveer drie dekades gelede het daar 'n radikale klemverskuiwing plaasgevind i.v.m. die aard van hierdie "algemene" werk van die Gees.

Calvyn het gesê: "Die krag van die Gees is uitgesprei oor alle dele van die wêreld om dit te bewaar in hul geskape staat en om aan hulle die krag en lewensbeweging te gee wat ons in alle lewende skepsels sien" (Kommentaar op Handelinge, aangehaal deur Walters 1949 20v, my vertaling). Ook Moody (1976) wys op die positiewe aard van die Gees se onderhoudende werk. Kuyper koppel alle oorheersende kragte aan die werk van die Gees, selfs die kolonialisme! "Owing to the divine pleasure, the Christian nations posses a moral and material superiority. England alone is perfectly able to control China, Japan, the whole of India and Turkey besides ... As the Christian nations return more and more to Judaism, and thence to heathenism, it is very possible that they will lose their material superiority"! (Kuyper 1975 599).

Mc Lelland som die houding van die Gereformeerde kerke in marxistiese terme op deur te sê dat hulle 'n burgeois-beeld van die deur-die-Gees-herskape mensheid nagevolg het (McLelland 29).

Maar vandag het die pendulum geswaai: "The Holy Spirit gives us a sense of identification with the rage of suffering, oppressed people everywhere (Cleage 1979 333). Die Heilige Gees is die revolusionêre $\mathrm{krag}$ wat die onderdruktes ervaar (332). Hy inspireer tot die daadwerklike opstand teen geïnstitueerde geweld (334).

Inderdaad moet ons die geeste onderskei. Ons mag nog na die een, nog na die ander kant toe uitgaan. Ook wat sy "algemene" werk betref is die Gees teenwoordig as Eersteling in die sondige bedeling. Geen instelling of gesindheid by enige ongelowige kan ongekwalifiseerd as gawe van die Gees beskryf word nie. Die feit is dat alles van hierdie wêreld nog onder die mag van die Bose lê. En die Gees is werkend teenwoordig, soos ook in Kain wat volgens Calvyn (1847, p.218) "though deprived of the Spirit of regeneration, were yet endued with gifts of no despicible kind; .... and we see, at the present time, that excellent gifts of the Spirit are diffused through the whole human race". Maar hierdie teenwoordigheid is die van Eersteling. Die gawes van die Gees is in die ongelowiges vasgevang in die net van die duiwel, en word deur hom gebruik. Daarom vertoon nóg nasionalisme-imperialisme, nóg revolusionisme voluit die merktekens van die Gees van Christus. In die gelowige se deelname aan hierdie wêreld moet die voorbehoud altyd duidelik wees: ons is in die wêreld maar nie van die wêreld nie. Daarom bestaan geen "christelike" nasionalisme nie. En ook geen "Christelike" terroristeorganisasie nie. Soos H. Berkhof sê: "The progress initiated by the 
Spirit leads to a sifting of the spirits, and is not only liberating but just as much disclosing and enslaving in its effects" $(1979, \mathrm{p515})$.

\section{DIE GEES EN STRUKTURE.}

Die Gees laat, volgens Bavinck (1929, p.320), die openbaring sy doel bereik, nl om die mensheid te herskep na die ewebeeld van God, om die koninkryk van God op aarde te stig, om die wêreld van die mag van die sonde te bevry, en om in en deur dit alles die Naam van die Here te verheerlik in al sy skepsels. In sy werk doen die Gees nie "half-a-job" nie (H. Berkhof 1979, p. 501). Nee, juis omdat Hy die Eersteling is van God se nuut-skepping, werk Hy ook in die strukture van die samelewing. Soos Blaser opmerk: ". . . Rechfertigung ohne Heiligung und ohne soziale Gestalt( bleibt) individualistisch religiös" (1977, p.15). "Die nuwe lewe wat Hy ons in hierdie ou wêreld gegee het, maak ons hier ontuis, maak ons byna oorgevoelig vir alles wat oud en vol onreg is, bring ons in opstand teen die lyding en pyn en frustrasie wat ons samelewing kenmerk" (König 1976, p. 27).

Hierdie strukturele werk van die Gees is ook deur Calvyn erken wat die gaping tussen die heilige en sekulêre oorbrug het met sy beskouing oor die waarde van die sekulêre roeping (Walters 1949, p. 348).

Die vraag is egter: Met watter standaarde moet ons meet? $\mathbf{H}$. Berkhof sê dit is "greater respect for the fellow human being, more room for his creative potential, deliberate care of the weak and disadvantaged, also greater freedom for every 'honest' conviction and by implication for the christian community, proclamation and service ... dissatisfaction with what has been achieved, the restless striving to improvement, the 'bad conscience"' (1979. p. 513). Die vraag is egter of ons in al hierdie sake regtig die Gees van God kan raaksien. Is "greater respect for the fellow human being" as sodanig 'n vrug van die werk van die Heilige Gees? Nie eerder van Humanisme nie?

Nou kan 'n mens egter nie sonder meer $H$. Berkhof se beskouing as humanisties tipeer nie. Hy erken baie uitdruklik ook die betreklike van enige strukturele verandering, die mag van die bose: "Sanctification and secularism progress together. With this sanctification of society the Spirit evokes an ambiguous and internally contradictory world, a society which is busy cutting down the gospel tree from which it is picking the fruits" $(1979$, p. 514). Die Heilige Gees se werk is in teenstelling tot enige materialistiese en bloot wêreldse sosiale en politieke program wat 'n humanistiese poging is om te verander of by wyse van evolusie of revolusie, en tot elke poging om hier 'n utopie te stig (vgl. Walters 1949, p. 483). Ons moet onderskei tussen ' $n$ vrywillige en totale aanvaarding van Bybelse strukturele reëls om die kwaad te bedwing en, aan die ander kant, 'n anti-chistelike diktatorskap wat sy hoop plaas op 'n utopie wat die erkenning van God uitsluit. Die werk van die Gees in die strukture 
van hierdie wêreld is nie totalitêr nie, maar vooruitwagtend op die Herskepper se koms.

Die regte antwoord op die strukturalisme is nie individualisme of 'n dualisme van hart en struktuur nie, maar 'n eskatologiese relatiwiteit: inderdaad moet gelowiges sosiaal-polities besig wees, maar altyd met voorbehoud: geen politieke program kan volledig God se wet navolg nie. Die rede vir ons deelname is nie om 'n nuwe Jerusalem te bou nie, maar om te getuig daarvan dat God alles sal nuutmaak, terwyl hierdie wêreld in die vuur van die Gees sal verteer. Ons verwag 'n nuwe aarde waarop geregtigheid sal woon. Waarvoor ons ons moet beywer is om voor God vlekkeloos en onberispelik te lewe (2 Petr. $3: 13,14)$ - ook in die strukture wat ons bou en verander; alle strukture van die huwelik af tot by die staat en ekonomie.

\section{DIE GEES EN DIE WEDERDOPERS.}

In art. 36 van die NGB bely ons dat ons die leer van die Wederdopers verwerp wat met oproerige mense die gereg omver wil werp en die gemeenskap van goedere wil invoer. In ons tyd ken ons egter die Anabaptiste wat meer 'n na-binne-gekeerde mistiese karakter vertoon. Hulle is afkerig van politiek, is ook pasifisties en besig met wêreldmyding. Maar daar is vandag in Latyns-Amerika pentekostalistiese groepe wat in huise saamkom, haarde van revolusionêre aksie en verset, sodat hulle blootstaan aan vervolging deur die staat. In Amerika is daar sterk verband tussen swart Pentekostalisme en Swart Mag" (Jonker 1981, p. 264).

Nou is die bekendste figuur uit die sestiende-eeuse anabaptistiese revolusionêres Thomas Münzer. En Ernst Bloch verheerlik hom as die eerste teoloog van die revolusie (Ibid, p. 263). Daar is dus 'n verband tussen Pentekostalisme en revolusionêre politiek!

Vir hierdie verband is daar twee redes: Eerstens is dit van beide groepe kenmerkend dat hulle die skepping negeer, die anabaptiste in 'n vertikale transendensie en dié van die Teologie van die Revolusie in ' $n$ horisontale transendensie. Tweedens is by beide groepe ook utopiese gedagtes gangbaar: by die Anabaptiste dié van die Millienialisme en by die Revolusionêre Teologie dié van die Marxisme.

'n Gereformeerde Pneumatologie wat totalitêr soos dié van Calvyn is (Walters 1949, p. 348), is inderdaad die Bybelse antwoord: God is deur sy Gees in hierdie wêreld besig, nie deur die natuurlike te elimineer of te negeer nie, maar deur ook die skepping voor te berei vir die radikale vernuwing wat die Here van die skepping sal bewerk met Sy wederkoms.

\section{SLOT: VENI CREATOR SPIRITUS.}

In die referaat het ek gepoog om die eenheid van die werk van die Gees in skepping en herskepping te beklemtoon. Inderdaad kan Pneumatologie nie teenoor Kosmologie of Eskatologie gestel word nie. Die Heilige Gees verbind ons aan die nuut-skepping, $\mathrm{Hy}$ ver- 
kondig dié boodskap in hierdie wêreld wat aan die verganklikheid oorgegee is. Die geskiedenis is die terrein waar ons met verlange die voltooiing van God se werk kan verwag.

In hierdie verwagting is ons aktief betrokke terwyl ons duidelik 'n eskatologiese voorbehoud het: die Gees is nl. die Eersteling, Apargé (Versteeg 1980: p. 371).

Daarom is die belangrikste werk wat 'n Gees-vervulde mens kan doen, dié van die gebed om die wederkoms van ons Here wanneer hy alles sal oordeel en nuut-skep. Terwyl ons so biddend wag op sy koms, sug ons saam met die skepping en die Gees vanweë die teens woordige tyd, terwyl ons met blydskap die werk van God deur sy Gees sien en ervaar.

Lesing gehou voor G.T.V. Soutpansberg 21 September 1982.

\section{BRONNELYS}

Bavinck, H. 1929: Gereformeerde Dogmatiek, Kok, Kampen.

Berkhof, H. 1979: Christian Faith, Eerdmans, Michigan.

Berkhof, L. 1949: Systematic Theology, The Banner of Truth Trust, Edinburg.

Blaser, K. 1977: Verstoss zur Pneumatologie, in: Geiger e.a. (Red): "Theologische Studien" nr. 121, Thrologischer Verlag. Zürich.

Calvin, J. 1847: Commentaries on the first book of Moses called Genesis" Vertaal deur King, J. The Calvin Translation Society, Edenburgh.

Cleage, H. B. 1979: Let's not waste the Holy Spirit' in Wilmore G. S. en Cone, J. H.: Black Theology, Orbis Books, New York, 332-339.

Floor, L. 1979: Hy wat met die Heilige Gees doop, Klasdiktaat, Potchefstroom. Hat.ingh, C. 1965: Die kerk en die Heilige Gees. in: D'Assonville, V. E. e.a. (Red): Die stryd om die kerk, Die Evangelis, Potchefstroom. nr. 2.

Honig, A. G. 1968: De Kosmische betekenis van Christus, Kok, Kampen.

Jonker, W. D. 1981: Die Gees van Christus, NGK Boekhandel, Pretoria.

Kônig, A. 1976: Meer duidelikheid oor die Gees?, NGK Boekhandel, Pretoria Kuyper, A. 1892: E Vot Dordraceno, Kok, Kampen.

Kuyper, A. 1975: The Work of the Holy Spirit, Vertaal deur De Vries, H, Eerdmans, Michigan.

Mc Lelland, J. The mundane work of the Spirit, Theol, Today XX11, 266-217. Moody, D. 1976: Spirit of the living God, Broadman Press, Tennessee.

Nurnberger, K. 1975: Sistematiese Teologie, Morawiese Boekdepot, Genadendal. Ridderbos, H. 1971: Paulus, Kok, Kampen.

Schaeffere, F. A. 1973: Leven door de Geest, Buijten en Schipperheijn, Amsterdam.

Van Rensburg, F. 1981: Die Kinders van God in Romeine 8" Gelewer voor NTWSA. 
Velema, W. H. sd: De leer van de Heilige Geest bij Abraham Kuyper', Kuelen, NV. 's Gravenhage.

Piterse, H. J. C. 1980: The Fruit of the Spirit in the life of the individual and Society, in Vorster. W. S. (Red): The Spirit in Biblical Perspective, Unisa, Pretoria, 66-80.

Verryn, T. D. 1980: Historical perspectives on the Emphasis on the Holy Spirit in ibid. 1-18.

Versieeg, J. P. 1980: "Christus en de Geest, Kok Kampen.

Vriezen, T. C. 1966: Hoofdlijnen der Theologie van het Oude Testament, Veenman en Zonen, N. V. Wageningen.

Walters, G. 1949: "The doctrine of the Holy Spirit in John Calvin, University of Edinburgh. 